\title{
Looking after number one
}

A merger of University College London and Imperial College, the top two research universities in Britain's capital city, may not in itself create a combined institution that is more internationally competitive.

$\mathrm{T}$ he proposal to merge Imperial College and University College London (UCL), creating Britain's largest research university by far (see Nature 419, 658; 2002), has been unveiled amid the warm and fuzzy hyperbole that tends to accompany such declarations of intent in business and in other fields. Much has been made of the world-beating prowess that such a merged institution could develop, of its potential ability to compete on a scale with the major US research universities, and of the vision of the principles involved.

After the smoke has cleared, however, it will be time for academics at both colleges to determine whether the merger of two of the country's top four research universities (the others are Oxford and Cambridge) will be in the best interests of their institutions, of London, or of British research as a whole.

A merger of Imperial and UCL would create a geographically bipolar institution in Britain's capital with around 28,000 students and an annual research income of some $\mathfrak{£} 400$ million (US\$620 million) - almost as much as the largest US research universities, such as Johns Hopkins University in Baltimore and the University of Michigan. In terms of research clout it would tower above its closest competitors in Britain.

The architects of the merger proposal are two former industrial managers: Richard Sykes, rector of Imperial College and former chief executive of the drug company GlaxoWellcome, and Derek Roberts, provost of UCL and former deputy managing director of GEC, the erstwhile British electrical-engineering conglomerate. Both men have argued that the benefits of scale that would be generated by the merger would help the new institution to compete with world-class research universities elsewhere, particularly in the United States.

\section{Spending pow er}

However, the élite US research universities - Harvard, Yale, the Massachusetts Institute of Technology, Princeton, Stanford and the University of California, Berkeley, would rank on most people's lists - are not in fact the largest in terms of their annual research spending. In fact, few members of this group currently spend much more than either UCL or Imperial.

The largest research operators in the United States include the University of Michigan and the University of California, Los Angeles, which, while maintaining fine standards in both teaching and research, are seldom viewed abroad as the crème de la crème of the US system. And the pecking order of US universities, in terms of the funding they receive from an array of public and private sources, shows a broad equivalence between the top institutions. In 1999, the last year for which the National Science Foundation has compiled data, the University of Michigan, the largest institution, spent \$509 million; Harvard, the nineteenth-largest, spent \$326 million.

In other words, US policy-makers and university administrators have not found it expedient, either academically or politically, to allow one institution to assume a dominant position above the others. Yet rivals will fear that this is very much what Imperial and UCL have in mind.

The British government is expected to publish a discussion paper later this year on the future of the country's universities, and it will probably encourage universities to consolidate their strengths on a regional basis. Mergers such as the one recently mooted between the University of Manchester and the University of Manchester Institute of Science and Technology would embody such consolidation (see Nature 416, 114; 2002).

But it is not clear that a single major research institution for a city as demographically and economically dominant as London fits well within this framework. London is surely large enough to support a diverse academic life. The Manchester proposal is supposed to help the city and its hinterland support an internationally competitive university. But how can it even compete domestically if Imperial and UCL create a behemoth with four times as many resources as anyone else in the country except Oxford and Cambridge?

\section{Open debate}

Sykes and Roberts each have experiences that suggest that big is not always beautiful. Sykes was involved in the merger in December 2000 between GlaxoWellcome and SmithKline Beecham, one of a recent spate of drug-industry mega-mergers whose performance to date has fallen short of investors' hopes. The merged company's share value has fallen from $£ 19$ at the time of the merger to less than $£ 14$ this week. And Roberts' former employer, GEC, has effectively collapsed, after buying up and consolidating every UK defence-sector player it could get its hands on, including such once-esteemed operations as Plessey and Ferranti.

None of which is to suggest that the merger of the London institutions is without merit. It is probably true, for example, that Imperial's attractiveness to undergraduates is limited by its lack of involvement in the social sciences and humanities, which a merger with UCL would provide. The two institutions appear at first glance to be a reasonably good fit. They have done well to announce their intentions at an early stage, and must now allow their academics to participate in as open a debate as possible on the merits of the proposal.

The governing councils that will be asked to endorse the merger proposal before the end of the year - and perhaps also the British parliament, which must then legislate to enable it - must consider what the merger is likely to achieve for the institutions, their staff, their students and the wider community.

Both colleges' largest problems in competing internationally are an ageing infrastructure and a difficulty in generating fresh income beyond the narrow constraints of UK public funding. Merger proponents will argue that a single, dominant university in London will be better able to attract such funds from international sources. Much of the debate on the merger will focus on whether that is indeed the case.

UCL and Imperial College each have distinct identities that inspire strong loyalty among students, staff and alumni. The pressing need for reform and flexibility at UK universities was highlighted only last week by Imperial's statement that it plans to introduce hefty student tuition fees if the government gives it the go-ahead. But even in such a climate - and even if it is accepted that financial viability is the dominant consideration - these identities are of value, and should not be discarded lightly. 